\title{
ANALISIS KETIMPANGAN PEMBANGUNAN DI PROVINSI BENGKULU (TELAAH POSISI 3 KABUPATEN INDUK)
}

\author{
Novi Tri Putri ${ }^{1)}$, Aris Almahmudi ${ }^{2)}$ \\ ${ }^{1,2}$ Jurusan Ekonomi Pembangunan,Fakultas Ekonomi dan Bisnis,Universitas Bengkulu,Indonesia \\ 1noviafr2606@gmail.com, ${ }^{2}$ aris@unib.ac.id
}

\begin{abstract}
This research aim was to analized the development disparities in Bengkulu Province, and the position change of 3 parent districts. The analysis method used descriptive anylisis with Klassen Typology and Williamson Index (WI), and used data from BPS Bengkulu Province publication (2002-2016). The result show WI for 2002, 2007 and 2016 in a row amount to 0,34; 0,40 and 0,37; which mean that the area expantion may cause the development disparities more equal or not. In the years of observation, position of 3 parent disticts always changing in the regional stucture of Bengkulu Province. It may caused of the dinamic development of the district, both parent and new districts.
\end{abstract}

Keywords : Development Disparities ${ }^{1}$, Area Expansion ${ }^{2}$, Klassen Typology $^{3}$, Williamson Index $^{4}$

\section{PENDAHULUAN}

Provinsi Bengkulu terdiri dari 10 kabupaten/kota, yang enam di antaranya merupakan kabupaten hasil pemekaran wilayah. Pada awalnya Provinsi Bengkulu hanya terdiri dari 4 kabupaten/kota, yaitu Kabupaten Bengkulu Utara, Kabupaten Bengkulu Selatan, Kabupaten Rejang Lebong dan Kota Bengkulu. Daerah pemekaran di Provinsi Bengkulu terbentuk melalui 3 Undang-undang (UU) yaitu UU No 3 Tahun 2003 tentang Pembentukan Kabupaten Muko-muko, Kabupaten Seluma dan Kabupaten Kaur di Provinsi Bengkulu; UU No 39 Tahun 2003 tentang Pembentukan Kabupaten Lebong dan Kabupaten Kepahiang di Provinsi Bengkulu; dan UU No 24 Tahun 2008 tentang Pembentukan Kabupaten Bengkulu Tengah di Provinsi Bengkulu.

Sama halnya dengan pemekaran di wilayah lain, pemisahan wilayah administrasi didorong oleh luasnya wilayah kabupaten asal yang menyebabkan pembangunan wilayah menjadi sulit dioptimalkan. Kuncoro (2012) menyatakan bahwa alasan mendasar terjadi pemekaran daerah adalah peningkatan kesejahteraan masyarakat lokal. Selama ini, sumber daya cenderung ditarik ke daerah induk sehingga daerah yang jauh dari pusat kekuasaan tertinggal. Berdasarkan hal ini dapat dikatakan bahwa dampak yang diharapkan dari 
pemekaran wilayah adalah pemerataan pembangunan sehingga daerah-daerah tertinggal dapat berkembang dengan lebih baik dan pembangunan di wilayah yang lebih luas menjadi lebih merata.

Pembangunan adalah upaya multidimensional yang meliputi perubahan pada berbagai aspek termasuk di dalamnya struktur sosial, sikap masyarakat, serta institusi nasional tanpa mengesampingkan tujuan awal yaitu pertumbuhan ekonomi, penanganan ketimpangan pendapatan dan perluasan kesempatan kerja (Widodo, 2006). Kompleksnya cakupan dalam kerangka pembangunan menyebabkan tanggung jawab pemerintah daerah menjadi sangat berat. Luasnya wilayah administrasi tentu juga menyebabkan munculnya kendala tersendiri bagi pemerintah setempat dalam pelaksanaan pembangunan daerah agar tujuan pembangunan dapat dicapai dengan optimal.

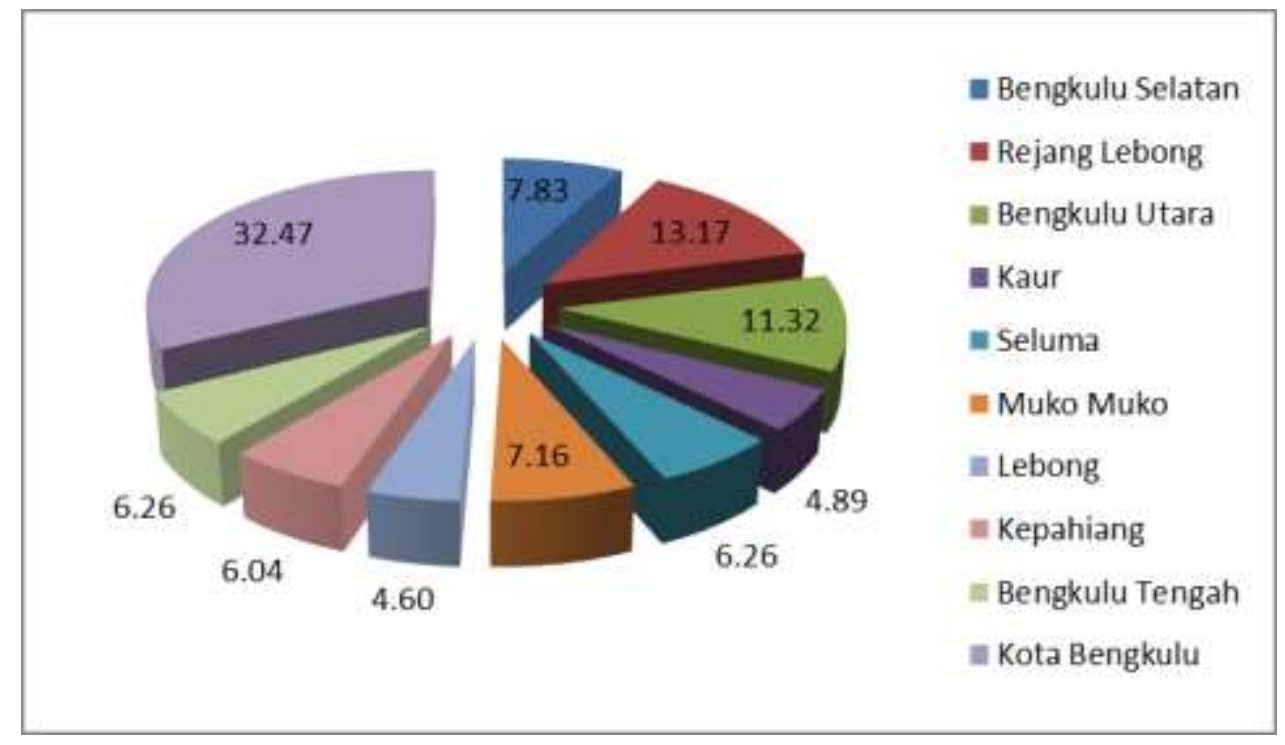

Gambar 1. Rata-rata Kontribusi per Tahun PDRB Kabupaten/Kota Terhadap PDRB Provinsi Bengkulu Tahun 2014-2016

Sumber: BPS Provinsi Bengkulu, data diolah

Jika dilihat besaran sumbangan PDRB masing-masing kabupaten/kota di Provinsi Bengkulu, maka selain Kota Bengkulu, kabupetan yang mampu memberikan sumbangan relatif lebih besar dibandingkan yang lain adalah Rejang Lebong, Bengkulu Utara, Bengkulu Selatan dan Muko-muko. Dapat dikatakan bahwa kabupaten-kabupaten yang menjadi induk pemekaran relatif masih memiliki peran yang cukup besar terhadap PDRB Provinsi Bengkulu. 
Selain besarnya nilai sumbangan PDRB, pertumbuhan PDRB menjadi variabel lain yang perlu diperhatikan dalam menganalisis dan mengetahuin perkembangan kondisi perekonomian wilayah. BPS (2017) menyatakan bahwa pertumbuhan ekonomi merupakan salah satu indikator yang amat penting dalam analisis pembangunan ekonomi suatu wilayah. Pertumbuhan ekonomi menunjukkan sejauh mana aktivitas perekonomian menghasilkan tambahan pendapatan masyarakat pada suatu periode tertentu. Mengingat pada dasarnya aktivitas perekonomian adalah suatu proses penggunaan faktor produksi menghasilkan output, maka proses ini pada akhirnya akan menghasilkan balas jasa terhadap faktor produksi yang dimiliki oleh masyarakat. Dengan adanya pertumbuhan ekonomi, diharapkan pendapatan masyarakat sebagai pemilik faktor produksi akan meningkat.

Tabel 1. Pertumbuhan PDRB ADHK Kabupaten/Kota dan Provinsi Bengkulu Tahun 2015-2016 (persen)

\begin{tabular}{lcc}
\hline \multicolumn{1}{c}{ Kabupaten/Kota } & Tahun & \\
& $\mathbf{2 0 1 5}$ & $\mathbf{2 0 1 6}$ \\
\hline Bengkulu Selatan & 4,89 & 5,32 \\
Rejang Lebong & 4,90 & 5,27 \\
Bengkulu Utara & 4,82 & 5,01 \\
Kaur & 4,73 & 5,34 \\
Seluma & 4,14 & 5,01 \\
Muko-muko & 5,36 & 5,85 \\
Lebong & 4,75 & 5,21 \\
Kepahiang & 5,41 & 5,74 \\
Bengkulu Tengah & 4,77 & 5,04 \\
Kota Bengkulu & 5,68 & 6,17 \\
Provinsi Bengkulu & 5,14 & 5,30 \\
\hline Sumber: BPS Provin
\end{tabular}

Sumber: BPS Provinsi Bengkulu, data diolah

Dari Tabel 1 terlihat bahwa pertumbuhan ekonomi Provinsi Bengkulu pada tahun 2015 adalah sebesar 5,14\% dan meningkat menjadi 5,30\% pada tahun berikutnya. Untuk kabupaten/kota, di tahun 2016 pertumbuhan tertinggi dialami oleh Kota Bengkulu sebesar 6,17\% dan terendah dialami oleh Kabupaten Bengkulu Utara dan Seluma yaitu sebesar $5,01 \%$.

Salah satu masalah penting yang dihadapi pemerintah daerah dalam proses pembangunan daerahnya adalah ketimpangan pembangunan. Semakin luas suatu daerah, maka masalah 
ketimpangan akan menjadi semakin pelik. Provinsi Bengkulu dalam perkembangannya tentu juga menghadapi masalah yang sama. Pemekaran wilayah yang telah terjadi menjadi bahasan tersendiri yang menarik dalam kaitannya dengan pemerataan pembangunan. Dampak pemekaran terhadap ketimpangan pembangunan dan posisi kabupaten induk pemekaran dalam perekonomian Provinsi Bengkulu menjadi bahasan utama dalam tulisan ini.

\section{TINJAUAN PUSTAKA}

\section{Pembangunan Ekonomi}

Arsyad (2005) menyatakan pembangunan ekonomi pada umunya didefinisikan sebagai suatu proses yang menyebabkan kenaikan pendapatan riil per kapita penduduk suatu negara dalam jangka panjang yang disertai oleh perbaikan sistem kelembagaan. Dari definisi tersebut maka pembangunan ekonomi mempunyai pengertian:

1. Suatu proses yang berarti perubahan yang terjadi terus menerus.

2. Usaha untuk menaikkan pendapatan per kapita, dan

3. Perbaikan sistem kelembagaan di segala bidang (misalnya ekonomi, politik, hukum, sosial dan budaya). Sistem kelembagaan ini bisa ditinjau dari 2 aspek yau: aspek perbaikan di bidang ranisasi (institusi) dan perbaikan di bidang regulasi (baik legal formal maupun informal).

Dari penjelasan tersebut, pembangunan ekonomi harus dipandang sebagai suatu proses agar saling keterkaitan dan saling mempengaruhi antara faktor-faktor yang menghasilkan pembangunan ekonomi tersebut dapat dilihat dan dianalisis.

Lebih lanjut Arsyad (2005) menjelaskan mengenai indikator pembangunan yang terdiri dari indikator moneter dan indikator non moneter. Indikator moneter terdiri dari pendapatan per kapita dan net economis welfare (indikator kesejahteraan ekonomi bersih). Sedangkan indikator non moneter terdiri dari indikator sosial, indeks kualitas hidup dan indeks pembangunan manusia, dan indeks campuran.

Banyak permasalahan yang dihadapi dalam proses pembangunan. Akan tetapi, secara umum ada beberapa masalah pokok yang menjadi masalah utama dalam pembangunan, yaitu pertumbuhan ekonomi, distribusi pendapatan, pengangguran dan kemiskinan. Pertumbuhan ekonomi dan distribusi pendapatan menjadi 2 hal yang banyak menjadi 
fokus penelitian dalam lingkup pembangunan ekonomi, dikarenakan 2 hal tersebut biasanya terjadi secara bertolak belakang atau lebih dikenal dengan trade-off antara pertumbuhan dan pemerataan.

\section{Pertumbuhan Ekonomi Regional dan Perbedaan Antarwilayah}

Beberapa daerah memiliki tingkat pendapatan dan prospek kerja yang lebih baik dibanding daerah lain. Investasi baru yang besar, akan memiliki pengaruh yang besar dalam pendapatan dan pekerjaan yang tersedia di daerah dan penting bagi para pembuat kebijakan untuk dapat memprediksi dengan tepat sehingga pengaruh yang muncul ikut diperhitungkan dalam pembuatan rencana fisik dan ekonomi daerah. Daerah berbeda dalam hal ukuran geografis dan ekonomi, karakteristik demografi, keberagaman industri, keahlian tenaga kerja, umur pabrik dan mesin, jalur perdagangan dengan daerah lain, pola konsumsi dan banyak karakteristik ekonomi yang lain (Armstrong \& Taylor ,2000)

Lebih lanjut Armstrong \& Taylor (2000) menyatakan bahwa perkembangan dalam teori pertumbuhan regional terbagi menjadi tiga kategori: model neoklasikal yang menekankan pada pengaruh sisi penawaran terhadap pertumbuhan; model Keynesian-type yang menekankan pada pentingnya permintaan terhadap ekspor daerah terhadap proses pertumbuhan; dan model penyebab kumulatif yang menekankan pada sifat dari proses pertumbuhan itu sendiri.

Adisasmita (2008) membagi pembahasan mengenai pertumbuhan wilayah menjadi dua, yaitu pertumbuhan dari dalam dan pertumbuhan wilayah dari luar. Pertumbuhan dari dalam adalah proses berlangsungnya pertumbuhan pembangunan dalam suatu wilayah ditinjau dari segi hubungan struktural (keterkaitan antarsektor) maupun dari segi hubungan fungsional (interaksi antar sub system dalam suatu wilayah). Pembahasan ini tidak memperhitungkan pengaruh keterkaitan dengan wilayah-wilayah di luar. Sedangkan pertumbuhan wilayah dari luar lebih menekankan perhatian pada keterkaitan suatu wilayah dengan wilayah lain di luarnya.

\section{Pemekaran Wilayah dan Disparitas Antardaerah}

Pemekaran wilayah di Indonesia adalah pembentukan wilayah administratif baru di tingkat provinsi serta kota dan kabupaten dari induknya. Landasan hukum untuk pemekaran wilayah di Indonesia adalah UU No. 32/2004 tentang Pemerintahan Daerah (Kuncoro, 
2012). Lebih lajut dijelaskan bahwa alasan mendasar terjadi pemekaran daerah adalah peningkatan kesejahteraan masyarakat lokal. Selama ini, sumber daya cenderung ditarik ke daerah induk sehingga daerah yang jauh dari pusat kekuasaan tertinggal.

Bank Dunia menyimpulkan bahwa ada 4 utama pendorong pemekaran wilayah, yaitu (Herawati):

1. Motif untuk efektifitas administrasi pemerintahan mengingat wilayah daerah yang begitu luas, penduduk yang menyebar dan adanya ketertinggalan dalam pembangunan.

2. Kecenderungan untuk homogenitas (etnis, bahasa, agama, urban rural, tingkat pendapatan). Beberapa pemekaran daerah lebih didasari motif ingin lepas dari himpitan "penindasan" kelompok lain atas dasar etnis, agama, dan lain.

3. Adanya kemanjaan fiskal yang dijamin UU dengan disediakannya DAU, DAK, Bagi Hasil dari Sumber Daya Alam dan disediakannya sumber-sumber pendapatan daerah.

4. Motif pemburu rente dari para elite. Pemekaran daerah banyak didasari motif karena ingin menjabat di Birokrasi Lokal dan DPRD. Selain itu, pemekaran daerah juga didasari motif untuk membangun kembali sejarah dan kekuasaan aristokrasi lama yang pernah pudak di masa lalu.

Pemekaran daerah menurut Undang-Undang No. 32 Tahun 2004 diharapkan: Pertama, mampu meningkatkan kualitas dan pemerataan pelayanan kepada masyarakat. Kedua, mampu meningkatkan percepatan pembangunan ekonomi, terutama pada daerah-daerah pinggiran. Ketiga, menfasilitasi pertumbuhan kehidupan demokrasi di daerah. Keempat, meningkatkan keamanan dan ketertiban di daerah. Kelima, memberikan kontribusi bagi persatuan dan kebangsaan.

Studi evaluasi pemekaran wilayah yang dilakukan oleh Bappenas \& UNDP (2008) menggunakan beberapa indikator fokus studi, yakni Perekonomian Daerah, Keuangan Daerah, Pelayanan Publik dan Aparatur Pemerintah Daerah, yang didasarkan pada PP 129/2000. Indikator yang digunakan sebagai ukuran kinerja ekonomi daerah adalah:

a. Pertumbuhan PDRB non migas

b. PDRB per kapita 
c. Rasio PDRB kabupaten terhadap PDRB provinsi

d. Angka kemiskinan.

\section{Indeks Williamson}

Indeks Williamson (IW) merupakan salah satu metode yang dapat digunakan untuk menganalisis disparitas antardaerah. Kegunaan dari penghitungan indeks ini adalah untuk mengetahui ketimpangan pembangunan ekonomi antardaerah dalam satu wilayah. Komponen yang sering digunakan sebagai indikator pembangunan suatu daerah adalah pendapatan per kapita. Meskipun demikian, penghitungan disparitas antardaerah dengan Indeks Williamson juga dapat dilakukan dengan menggunakan variabel selain pendapatan per kapita, misalnya digunakan variabel investasi per kapita untuk melihat seberapa besar ketimpangan penyerapan investasi antardaerah dalam satu wilayah.

Indeks Williamson dirumuskan sebagai berikut:

$I W=\frac{\sqrt{\sum_{i=1}^{n}(Y i-Y)^{2} * P i / P}}{Y}$

dimana:

IW = Indeks Williamson

$\mathrm{Yi}=$ Pendapatan per kapita daerah i yang menjadi bagian wilayah yang diteliti

$\mathrm{Y}=$ Pendapatan per kapita wilayah yang diteliti

$\mathrm{Pi}=$ Jumlah penduduk daerah $\mathrm{i}$

$\mathrm{P}=$ Jumlah penduduk total wilayah yang diteliti

Catatan:

Misalnya jika wilayah yang akan dihitung kesenjangan ekonominya adalah Provinsi, maka daerah i adalah Kabupaten/Kota pembentuk Provinsi bersangkutan.

Rumus Indeks Williamson ini akan menghasilkan angka indeks yang berkisar antara 0-1. Angka indeks $=0$ menandakan tidak terjadi kesenjangan ekonomi antardaerah dalam wilayah yang diteliti. Angka indeks yang lebih besar dari 0 menunjukkan adanya kesenjangan antardaerah. Semakin besar angka indeksnya berarti semakin besar pula tingkat kesenjangan ekonomi antardaerah.

\section{Tipologi Klassen}


Jika tingkat pertumbuhan ekonomi suatu daerah digabungkan secara sistimatis dengan tingkat pendapatan perkapita, maka akan dapat diperoleh suatu gambaran tentang struktur pertumbuhan ekonomi daerah. Analisa dengan menggunakan dua indikator tersebut oleh Klassen diklasifikasikan dalam empat kelompok yang masing-masing mempunyai karakteristik yang berbeda.

Empat klasifikasi daerah menurut Klassen:

1. Jika laju pertumbuhan PDRB suatu daerah > pertumbuhan PDRB rata-rata, serta pendapatan perkapita daerah tersebut > pendapatan per kapita rata-rata, maka daerah tersebut termasuk dalam kelompok daerah maju dan tumbuh cepat.

2. Jika laju pertumbuhan PDRB suatu daerah > pertumbuhan PDRB rata-rata, tetapi pendapatan perkapita daerah tersebut < pendapatan per kapita rata-rata, maka daerah tersebut termasuk dalam kelompok daerah berkembang cepat.

3. Jika laju pertumbuhan PDRB suatu daerah < pertumbuhan PDRB rata-rata, tetapi pendapatan perkapita daerah tersebut > pendapatan per kapita rata-rata, maka daerah tersebut termasuk dalam kelompok daerah maju tetapi tertekan.

4. Jika laju pertumbuhan PDRB suatu daerah < pertumbuhan PDRB rata-rata, tetapi pendapatan perkapita daerah tersebut $<$ pendapatan per kapita rata-rata, maka daerah tersebut termasuk dalam kelompok daerah kurang berkembang.

Jika pengelompokkan untuk dilakukan untuk melihat gambaran tentang struktur pertumbuhan ekonomi daerah dengan menggunakan indikator tingkat pertumbuhan ekonomi dan pendapatan per kapita, maka klasifikasi dapat dilakukan seperti pada Tabel 2.

Tabel 2. Klasifikasi Daerah Berdasarkan Tipologi Klassen

\begin{tabular}{|c|c|c|}
\hline $\mathrm{Y}_{\mathbf{Y}} \mathbf{R}$ & $\mathbf{R} \mathbf{i}<\mathbf{R}$ & $\mathbf{R} \mathbf{i}>\mathbf{R}$ \\
\hline $\mathbf{Y i}>\mathbf{Y}$ & Daerah maju tapi tertekan & Daerah maju dan tumbuh cepat \\
\hline $\mathbf{Y} \mathbf{i}<\mathbf{Y}$ & Daerah kurang berkembang & Daerah berkembang cepat \\
\hline \multicolumn{3}{|l|}{ dimana : } \\
\hline \multicolumn{3}{|c|}{$\mathrm{Ri}=$ laju pertumbuhan PDRB daerah $\mathrm{i}$} \\
\hline \multicolumn{3}{|c|}{$\mathrm{R}=$ laju pertumbuhan PDRB wilayah } \\
\hline \multicolumn{3}{|c|}{$\mathrm{Yi}=$ pendapatan per kapita daerah $\mathrm{i}$} \\
\hline
\end{tabular}


$\mathrm{Y}=$ pendapatan per kapita wilayah

$\mathrm{i}=$ daerah pembentuk wilayah yang lebih tinggi

\section{METODE PENELITIAN}

Penelitian ini bersifat deskriptif kuantitatif. Data yang digunakan adalah data sekunder meliputi gambaran umum kependudukan, data perekonomian daerah (PDRB), dan data penunjang lainnya. Semua data sekunder yang digunakan meliputi data 10 Kabupaten/Kota dan data Provinsi Bengkulu dengan rentang tahun analisis dari tahun 2002 sampai dengan tahun 2016 yang berasal dari data publikasi Badan Pusat Statistik Provinsi Bengkulu.

Analisis dimulai dengan menggunakan analisis deskriptif guna memberikan gambaran umum perekonomian Provinsi Bengkulu dan kabupaten/kota pembentuknya. Analisis deskriptif ini antara lain mengenai perbandingan nilai PDRB, pertumbuhan ekonomi, kondisi kependudukan. Lebih lanjut akan digunakan Indeks Williamson untuk mendapatkan nilai indeks ketimpangan pembangunan di tingkat Provinsi Bengkulu. Indeks ini akan dihitung pada beberapa titik tahun yaitu tahun 2002, tahun 2007 dan tahun 2016 (kondisi data terakhir). Setelah didapatkan indeks ketimpangan pembangunan, analisis akan dilanjutkan dengan pengklasifikasian kabupaten/kota ke dalam 4 kuadran dengan menggunakan Tipologi Klassen. Analisis ini ditujukan untuk mengetahui perubahan posisi 3 kabupaten induk yang mengalami pemekaran. Klasifikasi juga dilakukan di beberapa titik tahun.

Rincian metode analisis yang digunakan adalah sebagai berikut:

1. Analisis Deskriptif digunakan untuk memberikan gambaran mengenai kondisi perekonomian 10 kabupaten/kota dan Provinsi Bengkulu selama tahun pengamatan. Analisis ini mencakup perkembangan dan perbandingan nilai PDRB, pertumbuhan ekonomi, kondisi kependudukan dan analisis lain yang diperlukan.

2. Analisis Indeks Williamson (IW) digunakan untuk menghitung indeks ketimpangan pembangunan di Provinsi Bengkulu.

Dalam penelitian ini, kegunaan dari penghitungan Indeks Williamson adalah untuk mengetahui ketimpangan pembangunan ekonomi antarkabupaten/kota dalam Provinsi Bengkulu. Ketimpangan pembangunan Provinsi Bengkulu akan dilihat pada 
beberapa titik tahun agar dapat dibandingkan. Tahun yang dipilih adalah 1 tahun sebelum pemekaran wilayah terjadi dan tahun dengan data terakhir.

Komponen yang digunakan sebagai indikator pembangunan adalah pendapatan per kapita, sehingga formula Indeks Williamson yang digunakan sebagai berikut:

$$
I W=\frac{\sqrt{\sum_{i=1}^{n}(Y i-Y)^{2} * P i / P}}{Y}
$$

dimana:

$$
\begin{aligned}
& \text { IW = Indeks Williamson Provinsi Bengkulu } \\
& \mathrm{Yi} \text { = Pendapatan per kapita masing-masing kabupaten/kota } \\
& \mathrm{Y}=\text { Pendapatan per kapita Provinsi Bengkulu } \\
& \mathrm{Pi}=\text { Jumlah penduduk masing-masing kabupaten/kota } \\
& \mathrm{P}=\text { Jumlah penduduk total Provinsi Bengkulu }
\end{aligned}
$$

Angka indeks $=0$ menandakan tidak terjadi kesenjangan ekonomi antarkabupaten/kota dalam Provinsi Bengkulu. Angka indeks yang lebih besar dari 0 menunjukkan adanya kesenjangan antarkabupaten/kota. Semakin besar angka indeksnya berarti semakin besar pula tingkat kesenjangan ekonomi antarkabupaten/kota.

\section{Tipologi Klassen}

Tipologi Klassesn dalam penelitian ini menggunakan variabel tingkat pertumbuhan ekonomi kabupaten/kota di Provinsi Bengkulu yang digabungkan secara sistimatis dengan tingkat pendapatan perkapita, sehingga diperoleh suatu gambaran tentang struktur pertumbuhan ekonomi kabupaten/kota di Provinsi Bengkulu.

Analisa dengan menggunakan dua indikator tersebut kemudian kabupaten/kota diklasifikasikan dalam empat kelompok yang masing-masing mempunyai karakteristik yang berbeda. Empat klasifikasi tersebut sebagai barikut:

a. Jika laju pertumbuhan PDRB kabupaten/kota > pertumbuhan PDRB Provinsi Bengkulu, serta pendapatan perkapita kabupaten/kota tersebut > pendapatan per kapita Provinsi Bengkulu, maka kabupaten/kota tersebut termasuk dalam kelompok kabupaten/kota maju dan tumbuh cepat. 
b. Jika laju pertumbuhan PDRB suatu kabupaten/kota > pertumbuhan PDRB Provinsi Bengkulu, tetapi pendapatan perkapita kabupaten/kota tersebut $<$ pendapatan per kapita Provinsi Bengkulu, maka kabupaten/kota tersebut termasuk dalam kelompok kabupaten/kota berkembang cepat.

c. Jika laju pertumbuhan PDRB suatu kabupaten/kota < pertumbuhan PDRB Provinsi Bengkulu, tetapi pendapatan perkapita kabupaten/kota tersebut > pendapatan per kapita Provinsi Bengkulu, maka kabupaten/kota tersebut termasuk dalam kelompok kabupaten/kota maju tetapi tertekan.

d. Jika laju pertumbuhan PDRB suatu kabupaten/kota $<$ pertumbuhan PDRB Provinsi Bengkulu, tetapi pendapatan perkapita kabupaten/kota tersebut < pendapatan per kapita Provinsi Bengkulu, maka kabupaten/kota tersebut termasuk dalam kelompok kabupaten/kota kurang berkembang

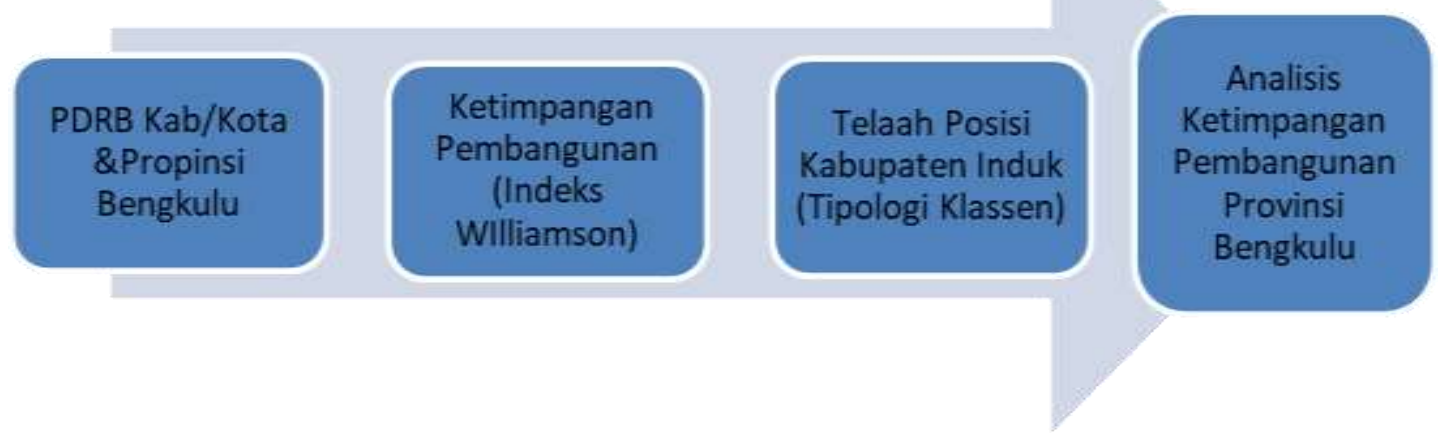

Gambar 2. Kerangka Penelitian

\section{HASIL DAN PEMBAHASAN}

\section{Perbandingan Kondisi Kabupaten/Kota dan Provinsi Bengkulu}

Dari 10 kabupaten/kota yang ada di Provinsi Bengkulu, enam di antaranya merupakan kabupaten hasil pemekaran wilayah. Provinsi Bengkulu memiliki 3 kabupaten induk, yaitu Kabupaten Bengkulu Utara, Kabupaten Bengkulu Selatan, Kabupaten Rejang Lebong dan 1 Kota Bengkulu yang tidak mengalami pemekaran wilayah. Pada tahun 2003 dan 2008 diterbitkan Undang Undang yang mendasari pembentukan daerah pemekaran. Daerah pemekaran di Provinsi Bengkulu terbentuk melalui 3 Undang-undang (UU) yaitu UU No 3 Tahun 2003 tentang Pembentukan Kabupaten Muko-muko, Kabupaten Seluma dan Kabupaten Kaur di Provinsi Bengkulu; UU No 39 Tahun 2003 tentang Pembentukan 
Kabupaten Lebong dan Kabupaten Kepahiang di Provinsi Bengkulu; dan UU No 24

Tahun 2008 tentang Pembentukan Kabupaten Bengkulu Tengah di Provinsi Bengkulu.

Tabel 3. Jumlah Penduduk Berdasarkan Kabupaten/Kota di Provinsi Bengkulu Tahun 2002, 2007 dan 2016 (Jiwa)

\begin{tabular}{lccc}
\hline \multicolumn{1}{c}{ Kabupaten/Kota } & $\mathbf{2 0 0 2}$ & $\begin{array}{c}\text { Tahun } \\
\mathbf{2 0 0 7}\end{array}$ & $\mathbf{2 0 1 6}$ \\
\hline Bengkulu Selatan & 385.813 & 137.203 & 153.930 \\
Rejang Lebong & 456.044 & 249.174 & 257.498 \\
Bengkulu Utara & 494.552 & 339.873 & 293.099 \\
Kaur & - & 112.528 & 117.269 \\
Seluma & - & 162.104 & 187.807 \\
Mukomuko & - & 138.590 & 181.343 \\
Lebong & - & 89.690 & 111.063 \\
Kepahiang & - & 116.882 & 133.703 \\
Bengkulu Tengah & - & - & 109.593 \\
Kota Bengkulu & 304.188 & 270.079 & 359.488 \\
Provinsi Bengkulu & 1.640 .597 & 1.616 .663 & 1.904 .793 \\
\hline
\end{tabular}

Sumber: BPS Provinsi Bengkulu

Tabel 3 menunjukkan perkembangan jumlah penduduk di kabupaten/kota di Provinsi Bengkulu pada 3 tahun pengamatan. Pada tahun 2002 Bengkulu Utara merupakan daerah dengan jumlah penduduk tertinggi, sedangkan jumlah penduduk terendah berada di Kota Bengkulu.

Tahun 2007, jumlah kabupaten/kota di Provinsi Bengkulu menjadi 9, dimana daerah pemekaran berasal dari Kabupaten Bengkulu Utara (1 kabupaten), Bengkulu Selatan (2 kabupaten), dan Rejang Lebong (2 kabupaten). Hal ini menjadi salah satu sebab mengapa Bengkulu Utara tetap menjadi daerah dengan jumlah penduduk terbanyak. Pada tahun 2016, daerah pemekaran bertambah 1 kabupetan yang berasal dari Bengkulu Utara, terlihat jumlah penduduk terbanyak pada tahun ini ada di Kota Bengkulu.

Selanjutnya, perbandingan nilai PDRB/kapita antar kabupaten/kota ditunjukkan oleh Tabel 4 dimana terlihat bahwa nilai PDRB/kapita selalu mengalami peningkatan. Di setiap tahun pengamatan, Kota Bengkulu selalu menjadi daerah dengan PDRB tertinggi. Hal ini tidak mengherankan, dikarenakan Kota Bengkulu merupakan pusat pemerintahan Provinsi Bengkulu dimana aktivitas ekonomi terpusat paling besar di sini. 
Tabel 4. PDRB/Kapita Per Tahun Berdasarkan Kabupaten/Kota dan Provinsi Bengkulu Tahun 2002, 2007 dan 2016 (Rupiah)

\begin{tabular}{lccc}
\hline \multicolumn{1}{c}{ Kabupaten/Kota } & $\mathbf{2 0 0 2}$ & $\mathbf{2 0 0 7}$ & $\mathbf{2 0 1 6}$ \\
\hline Bengkulu Selatan & 2.012 .455 & 3.580 .702 & 20.329 .697 \\
Rejang Lebong & 4.323 .061 & 5.884 .631 & 20.441 .028 \\
Bengkulu Utara & 2.335 .633 & 3.055 .175 & 15.403 .677 \\
Kaur & - & 1.903 .478 & 16.667 .899 \\
Seluma & - & 1.874 .883 & 13.265 .220 \\
Mukomuko & - & 3.520 .102 & 15.857 .878 \\
Lebong & - & 4.972 .026 & 16.535 .225 \\
Kepahiang & - & 5.417 .840 & 18.143 .392 \\
Bengkulu Tengah & - & - & 22.789 .387 \\
Kota Bengkulu & 4.460 .695 & 6.692 .073 & 36.406 .126 \\
Provinsi Bengkulu & 3.206 .101 & 4.260 .938 & 21.039 .935 \\
\hline
\end{tabular}

Sumber: BPS Provinsi Bengkulu, data diolah

Perbandingan tingkat pertumbuhan ekonomi kabupaten/kota dan provinsi pada tahun 2016 dapat dilihat pada Gambar 3. Pertumbuhan ekonomi tertinggi dicapai oleh Kota Bengkulu yaitu sebesar 6,17\% disusul Kabupaten Mukomuko sebesar 5,85\%. Kabupaten yang memiliki tingkat pertumbuhan ekonomi di bawah provinsi adalah Bengkulu Utara, Seluma, Bengkulu Tengah dan Rejang Lebong.

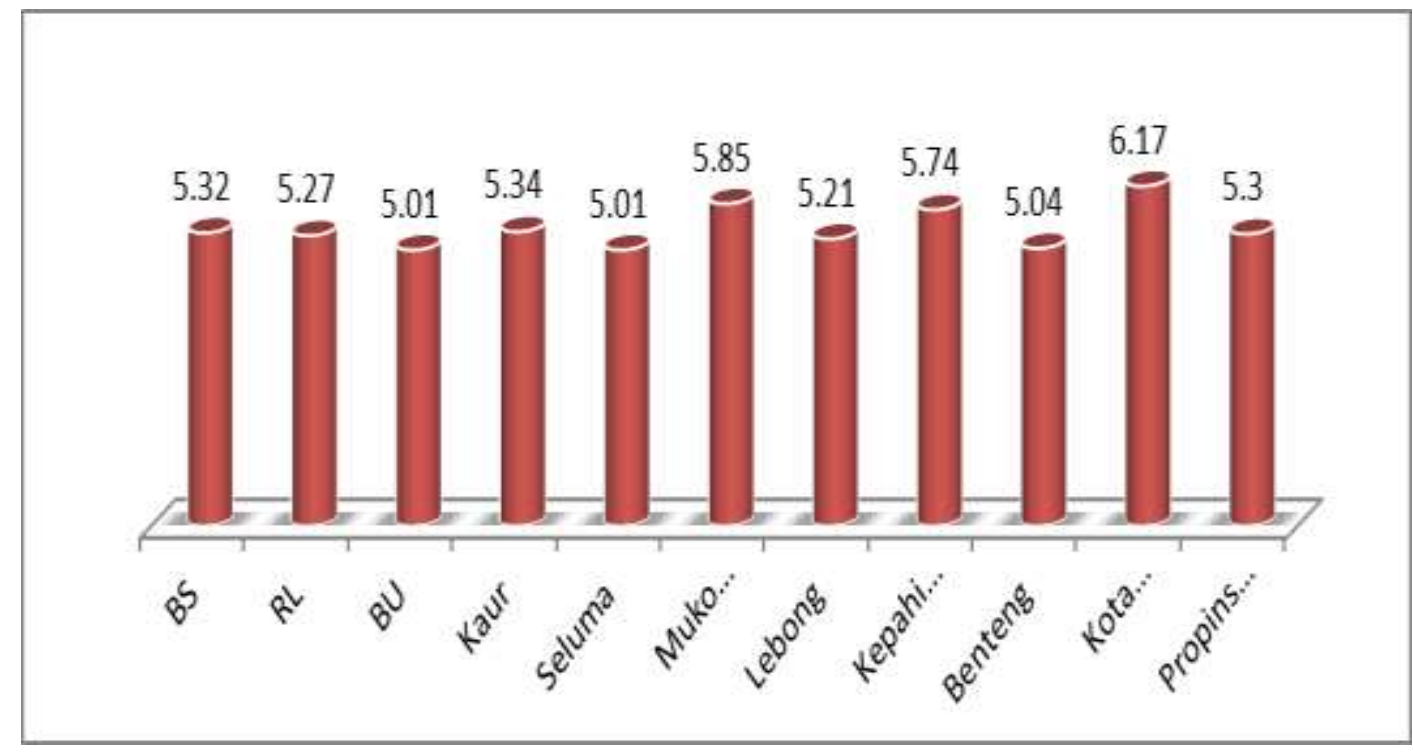

Gambar 3. Pertumbuhan Ekonomi Kabupaten/Kota dan Provinsi Bengkulu Tahun 2016 


\section{Analisis Ketimpangan Pembangunan}

Hasil penghitungan IW untuk 3 tahun pengamatan dapat dilihat pada Gambar 4.

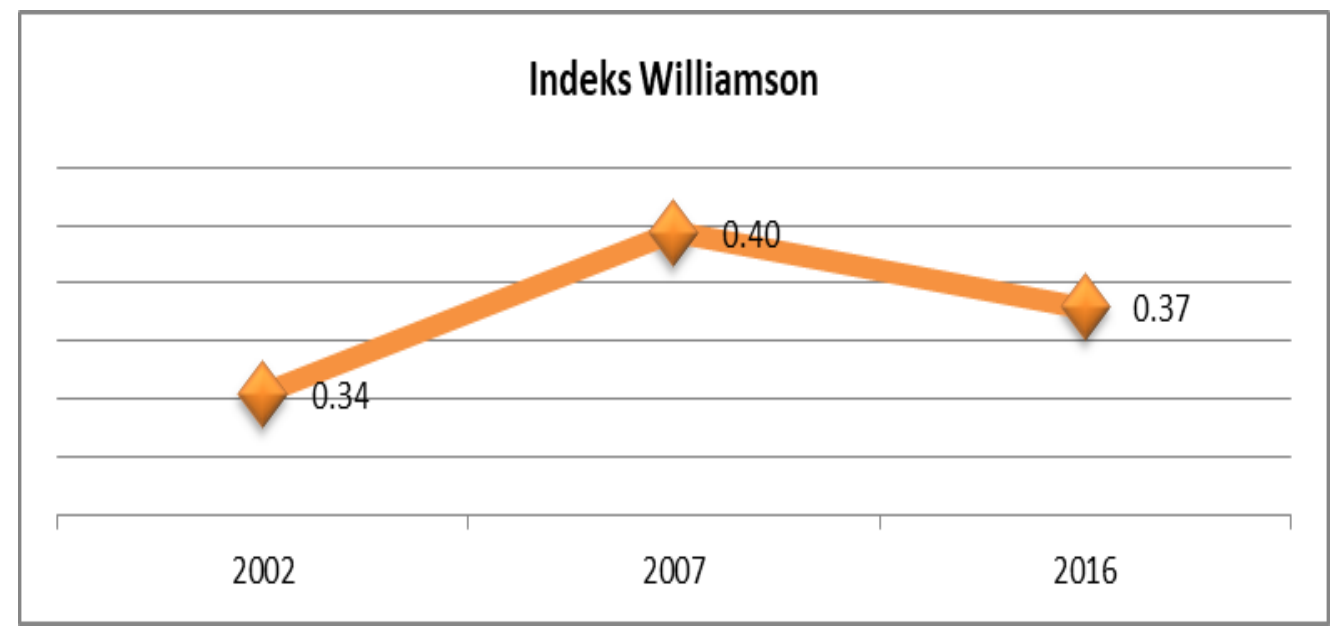

Gambar 4. Indeks Williamson Provinsi Bengkulu Tahun 2001, 2007 dan 2016

Sumber: hasil penelitian

Pada tahun 2002, Provinsi Bengkulu memiliki angka IW sebesar 0,34 yang berarti bahwa 4 daerah pembentuk Provinsi Bengkulu memiliki ketimpangan pembangunan yang relatif rendah. Pendapatan per kapita (PDRB/kapita) kabupaten/kota seperti terlihat pada Tabel 5.2. menunjukkan 2 daerah memiliki pendapatan perkapita di kisaran 4 jutaan, dan 2 lagi di kisaran 2 jutaan. atau dapat dikatakan bahwa daerah mengerucut menjadi 2 kelompok yang memiliki pendapatan per kapita relatif sama.

Dari 3 tahun pengamatan terlihat IW tertinggi ada di tahun 2007 atau setelah terbentuknya 5 kabupaten baru. Angka ini menunjukkan bahwa pembangunan antarkabupaten/kota di Provinsi Bengkulu menjadi semakin timpang dibandingkan pada tahun 2002. Jika dihubungkan dengan pemekaran wilayah yang terjadi, ketimpangan pembangunan dapat menjadi lebih tinggi jika daerah-daerah hasil pemekaran memiliki kinerja ekonomi yang relatif rendah atau tidak dapat berkembang dengan baik. Hal ini sangat mungkin terjadi dikarenakan daerah baru biasanya belum dapat mengoptimalkan potensi ekonomi yang ada termasuk adanya lag dalam penyelenggaraan pemerintahan dan aktivitas ekonomi akibat terpisahnya dari kabupaten induk.

Selain dikarenakan kinerja ekonomi daerah pemekaran, ketimpangan pembangunan juga dapat menjadi semakin tinggi jika daerah induk kehilangan sumber pertumbuhan ekonomi yang berasal dari penduduk dengan produktivitas yang relatif lebih tinggi. Hal ini akan 
mengakibatkan kabupaten induk mengalami penurunan kinerja ekonomi yang berdampak pada makin rendahnya pendapatan per kapita daerah.

Tahun 2016 Provinsi Bengkulu memiliki angka IW sebesar 0,37 yang mengindikasikan bahwa ketimpangan pembangunan setelah terbentuknya 1 kabupaten lagi di 2008 menjadi semakin rendah jika dibandingkan tahun 2007. Terbentuknya Bengkulu Tengah yang berasal dari Kabupaten Bengkulu Utara memecah sumber pertumbuhan ekonomi Bengkulu Utara yang sebelumnya memang berada pada daerah-daerah yang memiliki jarak lokasi relatif jauh. Munculnya Bengkulu Tengah yang diuntungkan secara geografis berada di perbatasan dengan Kota Bengkulu menyebabkan daerah termuda ini menjadi daerah yang menjanjikan, dimana pendapatan per kapita masyarakatnya relatif lebih tinggi dibandingkan kabupetan lain. Hal ini menjadi salah satu pendorong yang menyeimbangkan ketimpangan pendapatan per kapita, sehingga IW Provinsi Bengkulu menjadi lebih rendah.

\section{Analisis Klasifikasi Kabupaten/Kota}

Klasifikasi kabupaten/kota dilakukan dengan meggunakan Tipologi Klassesn. Variabel yang digunakan adalah tingkat pertumbuhan ekonomi kabupaten/kota dan tingkat pendapatan perkapita (PDRB per kapita), sehingga diperoleh suatu gambaran tentang struktur pertumbuhan ekonomi kabupaten/kota di Provinsi Bengkulu untuk tahun 2002, 2007 dan 2016 masing-masing pada 3 tabel berikut.

Tabel 5. Klasifikasi Kabupaten/Kota Tahun 2002

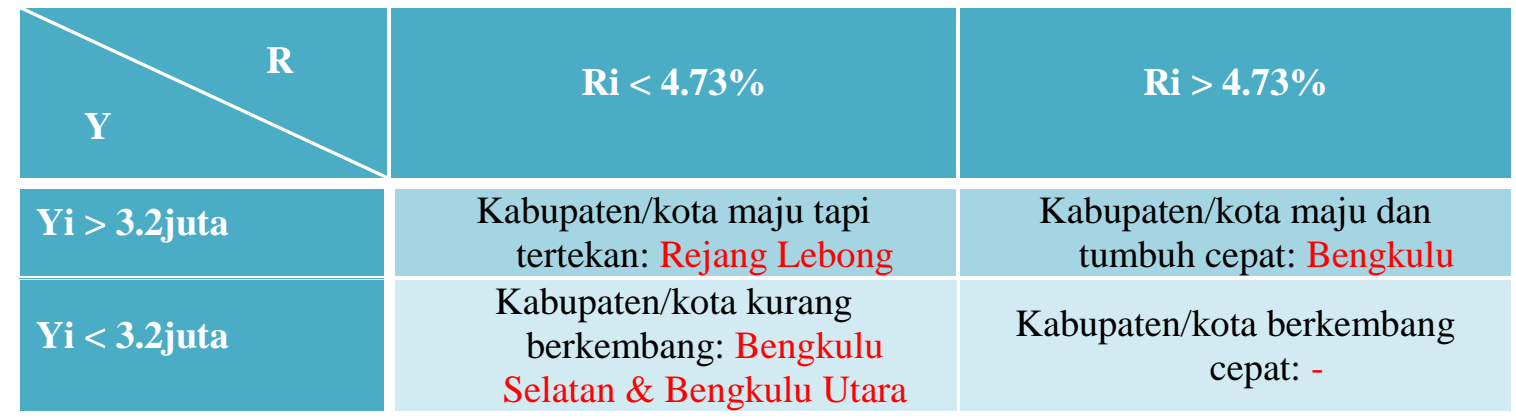

Pada tahun 2002, Kota Bengkulu menjadi daerah yang memimpin dalam hal pertumbuhan ekonomi dan tingkat pendapatan per kapita masyarakatnya sehingga Bengkulu menjadi kota maju yang tumbuh cepat dibandingkan 3 daerah lainnya. Rejang Lebong adalah kabupaten maju dengan pendapatan per kapita di atas propinsi akan tetapi laju 
pertumbuhannya lebih rendah sehingga masuk dalam klasifikasi kabupaten maju tapi tertekan. 2 daerah lain, yaitu Bengkulu Selatan dan Bengkulu Utara ada di kuadran yang sama dan masuk dalam klasifikasi kabupaten kurang berkembang.

Titik tahun pengamatan kedua adalah tahun 2007 yaitu 4 tahun setelah 5 kabupaten baru hasil pemekaran terbentuk pada tahun 2003. Tahun 2007 diambil karena pada tahun 2008 kembali terbentuk 1 kabupaten baru, dan rentang waktu 4 tahun diasumsikan bahwa daerah baru telah dapat menjalankan aktivitas pemerintahan maupun ekonomi dengan relatif stabil.

Tabel 6. Klasifikasi Kabupaten/Kota Tahun 2007

\begin{tabular}{|c|c|c|}
\hline . & $\mathbf{R i}<6.03 \%$ & $\mathrm{Ri}>6.03 \%$ \\
\hline$Y \mathrm{i}>4.2 \mathrm{juta}$ & $\begin{array}{c}\text { Kabupaten/kota maju tapi } \\
\text { tertekan: Lebong }\end{array}$ & $\begin{array}{l}\text { Kabupaten/kota maju dan } \\
\text { tumbuh cepat: Bengkulu. } \\
\text { Rejang Lebong. Kepahiang }\end{array}$ \\
\hline $\mathrm{Yi}<4.2 \mathrm{juta}$ & $\begin{array}{l}\text { Kabupaten/kota kurang } \\
\text { berkembang: Kaur \& } \\
\text { Mukomuko }\end{array}$ & $\begin{array}{c}\text { Kabupaten/kota berkembang } \\
\text { cepat Bengkulu Selatan. } \\
\text { Seluma \& Bengkulu Utara }\end{array}$ \\
\hline
\end{tabular}

Pada tahun 2007, terlihat bahwa Kota Bengkulu masih tetap menjadi daerah yang memimpin pembangunan di Provinsi Bengkulu. Rejang Lebong yang pada tahun 2002 masuk dalam klasifikasi maju tapi tertekan dapat menjadi lebih baik dan menjadi daerah maju dan tumbuh cepat. 2 kabupaten induk lainnya yaitu Bengkulu Selatan dan Bengkulu Utara juga mengalami perkembangan pembangunan dan dapat berpindah ke klasifikasi kabupaten berkembang cepat. Untuk kabupaten baru hasil pemekaran, terlihat yang memiliki kinerja lebih baik adalah Lebong dan Seluma. Sedangkan Kaur dan Mukomuko berada pada klasifikasi daera kurang berkembang.

Kabupaten Bengkulu Tengah menjadi kabupaten paling muda di Provinsi Bengkulu, setelah terbentuk pada tahun 2008 hasil pemekaran dari Kabupaten Bengkulu Utara. Klasifikasi kabupaten/kota untuk tahun 2016 dapat dilihat pada Tabel 7. 
Tabel 7. Klasifikasi Kabupaten/Kota Tahun 2016

\begin{tabular}{|c|c|c|}
\hline & $\mathrm{Ri}<4.73 \%$ & $\mathrm{Ri}>4.73 \%$ \\
\hline Yi > 21 juta & $\begin{array}{c}\text { Kabupaten/kota maju tapi tertekan: } \\
\text { Bengkulu Tengah }\end{array}$ & $\begin{array}{l}\text { Kabupaten/kota maju dan } \\
\text { tumbuh cepat: Bengkulu }\end{array}$ \\
\hline Yi $<21$ juta & $\begin{array}{c}\text { Kabupaten/kota kurang berkembang: } \\
\text { Bengkulu Utara. Rejang Lebong. } \\
\text { Seluma \& Lebong }\end{array}$ & $\begin{array}{c}\text { Kabupaten/kota berkembang } \\
\text { cepat : Bengkulu Selatan. } \\
\text { Kaur. Kepahiang \& } \\
\text { Mukomuko }\end{array}$ \\
\hline
\end{tabular}

Terlihat bahwa Kota Bengkulu selalu berada di kuadran kota maju dan tumbuh cepat. Rejang Lebong mengalami kemunduran kinerja yang paling besar sehingga pada tahun 2016 menjadi kabupaten kurang berkembang (pada 2007 klasifikasi kabupaten maju dan tumbuh cepat). Bengkulu Utara juga mengalami penurunan kinerja pertumbuhan ekonomi dibandingkan daerah lainnya sehingga menjadi kabupaten yang ikut menemani Rejang Lebong di kuadran kurang berkembang. Bengkulu Selatan tetap ada di kuadran berkembang cepat.

Untuk kabupaten hasil pemekaran, Bengkulu Tengah menunjukkan perkembangan yang baik dan masuk dalam kuadran maju tapi tertekan. Seluma dan Lebong mengalami penurunan kinerja sehingga pada 2016 ada di kuadran kabupaten kurang berkembang. Kabupaten lainnya yaitu Kaur, Kepahiang dan Mukomuko masuk dalam klasifikasi kabupaten berkembang cepat.

Jika dibandingkan kondisi pada 3 tahun pengamatan, dapat disimpulkan bahwa posisi Kota Bengkulu sebagai daerah yang memimpin pembangunan tidak dapat digeser oleh kabupaten yang ada di Provinsi Bengkulu. Hal ini disebabkan karena Bengkulu merupakan pusat pemerintahan provinsi yang berarti aktivitas ekonomi paling besar ada di daerah ini. Selain itu, sarana prasarana pendukung pembangunan daerah, kualitas sumber daya manusia maupun akses informasi dan transportasi juga tersedia paling baik.

Fenomena yang menarik untuk diperhatikan adalah posisi 3 kabupaten induk pemekaran, yaitu Rejang Lebong, Bengkulu Selatan dan Bengkulu Utara. Untuk Rejang Lebong, posisinya selalu berubah di 3 tahun pengamatan. Pada tahun 2002, Rejang Lebong ada di klafisikasi maju tapi tertekan, menjadi kabupaten maju dan tumbuh cepat di 2007 dimana 
kabupaten hasil pemekarannya yaitu Kepahiang ada di kuadran yang sama dan Lebong di kuadran maju tapi tertekan. Hal ini mengindikasikan bahwa pemekaran Rejang Lebong menjadi 3 kabupaten memberikan dampak yang baik bagi daerah tersebut. Di tahun 2016, Rejang Lebong dan 2 kabupaten hasil pemekarannya menunjukkan kinerja yang relatif lebih rendah dibanding daerah yang lain yang menyebabkan 3 kabupaten tersebut mengalami penurunan klasifikasi.

Bengkulu Selatan pada tahun 2002 ada di klasifikasi daerah kurang berkembang. Setelah pemekaran wilayah terjadi, posisi kabupaten ini menjadi lebih baik dan masuk di klasifikasi daerah berkembang cepat pada 2007 dan tidak berubah di 2016. Kabupaten Kaur yang merupakan hasil pemekaran Bengkulu Selatan ada di kuadran daerah terbelakang pada 2007 dan menjadi lebih baik di 2016 dengan klasifikasi daerah berkembang cepat. Sebaliknya, Kaur yang juga merupakan kabupaten pemekaran Bengkulu Selatan ada di kuadran berkembang cepat pada 2007 menjadi kurang berkembang di 2016.

Kabupaten induk yang ketiga, yaitu Bengkulu Utara menunjukkan kinerja yang relatif tidak banyak berubah. Pada awalnya di tahun 2002, Bengkulu Utara ada di klasifikasi kurang berkembang. Pada tahun 2007 setelah Mukomuko dimekarkan, posisi Bengkulu Utara menjadi daerah berkembang cepat. Akan tetapi, setelah pemekaran wilayah kembali dilakukan dengan menghasilkan kabupaten Bengkulu Tengah, posisi Bengkulu Utara kembali ke klasifikasi daerah kurang berkembang. Kabupaten Mukomuko pada 2007 merupakan daerah kurang berkembang dan menjadi daerah berkembang cepat di tahun 2016. Sedangkan Bengkulu Tengah masuk ke dalam klasifikasi daerah maju tapi tertekan.

Posisi kabupaten induk yang berubah-ubah dapat dikarenakan oleh kinerja daerah lain atau kabupaten induk bersangkutan. Jika klasifikasi daerah menjadi lebih rendah, hal ini dapat dikarenakan kinerja kabupaten lain yang lebih baik sehingga kabupaten induk tertinggal atau dikarenakan daerah yang menjadi kabupaten baru awalnya adalah sumber pertumbuhan ekonomi bagi kabupaten induk. Sebaliknya, jika klasifikasi menjadi lebih baik, hal ini dapat dikarenakan kinerja kabupaten lain yang lebih rendah atau kabupaten hasil pemekaran sebelumnya merupakan daerah "beban" bagi kabupaten induk, sehingga ketika daerah "beban" dilepaskan kabupaten induk dapat berkembang lebih baik. 


\section{KESIMPULAN}

Dari hasil penelitian yang telah dilakukan dapat disimpulkan beberapa hal, yaitu:

1. Nilai Indeks Williamson Provinsi Bengkulu untuk tahun 2002, 2007 dan 2016 berturut-turut adalah sebesar 0,34;0,40 dan 0,37. Hal ini menunjukkan bahwa pemekaran wilayah dapat menyebabkan ketimpangan pembangunan menjadi semakin tinggi atau sebaliknya.

2. Jika dihubungkan dengan pemekaran wilayah yang terjadi, ketimpangan pembangunan dapat menjadi lebih tinggi jika daerah-daerah hasil pemekaran memiliki kinerja ekonomi yang relatif rendah atau tidak dapat berkembang dengan baik, dikarenakan daerah baru biasanya belum dapat mengoptimalkan potensi ekonomi yang ada termasuk adanya lag dalam penyelenggaraan pemerintahan dan aktivitas ekonomi akibat terpisahnya dari kabupaten induk. Selain itu, ketimpangan pembangunan juga dapat menjadi semakin tinggi jika daerah induk kehilangan sumber pertumbuhan ekonomi yang berasal dari penduduk dengan produktivitas yang relatif lebih tinggi yang mengakibatkan kabupaten induk mengalami penurunan kinerja ekonomi yang berdampak pada makin rendahnya pendapatan per kapita daerah. Sebaliknya, ketimpangan pembangunan dapat menjadi lebih rendah jika daerah hasil pemekaran maupun daerah induk dapat berkembang dengan baik setelah pemekaran terjadi.

3. Posisi 3 kabupaten induk dalam struktur daerah di Provinsi Bengkulu selama tahun pengamatan selalu berubah. Hal ini disebabkan dinamisnya perkembangan daerah, baik hasil pemekaran maupun daerah induk yang ditinggalkan.

\section{KETERBATASAN DAN REKOMENDASI}

Alat analisis dan data yang digunakan bersifat makro sehingga hanya memberikan gambaran perkembangan daerah secara umum. Dampak pemekaran wilayah hanya dilihat dari sisi pemerataan pembanguan dengan variabel pendapatan per kapita dan pertumbuhan ekonomi. Berdasarkan kesimpulan dan keterbatasan, maka direkomendasikan untuk penelitian selanjutnya agar dapat melengkapi alat analisis dan data yang lebih detail (mikro) mengenai perkembangan perekonomian daerah yang diteliti. Selain itu dapat dipertimbangkan penggunaan variabel ekonomi dan sosial lainnya sebagai indikator dampak pemekaran wilayah agar didapatkan gambaran dampak pemekaran yang lebih lengkap. Sementara itu, untuk pemerintah dalam proses pemekaran wilayah hendaknya memperhatikan kesiapan daerah yang akan dimekarkan serta perlunya evaluasi terhadap 
dampak pemekaran wilayah baik terhadap daerah induk maupun daerah hasil pemekaran agar proses pemekaran wilayah dapat memberikan hasil yang optimal bagi pemerataan pembangunan dan perkembangan daerah bersangkutan.

\section{DAFTAR PUSTAKA}

Adisasmita. R. (2008). Pengembangan Wilayah Konsep dan Teori. Edisi Pertama. Yogyakarta: Graha Ilmu.

Armstrong. H.. \& Taylor. J. (2001). Regional Economics and Policy. 3th edition. UK. Blackwell Publisher.

Arsyad. L. (1999). Ekonomi Pembangunan. Edisi Keempat. Yogyakarta: STIE YKPN.

Arsyad. L. (2005). Pengantar Perencanaan dan Pembangunun Ekonomi Kabupaten/kota. Edisi Kedua. Yogyakarta: BPFE-UGM.

Bappenas \& UNDP. (2008). Studi Evaluasi Dampak Pemekaran Daerah 2001-2007. BRIDGE

BPS. (2018). Provinsi Bengkulu dalam Angka 2018. Bengkulu: Badan Pusat Statistik Provinsi Bengkulu. www.bengkulu.bps.go.id

BPS. (2017). Tinjauan PDRB Kabupaten/Kota Provinsi Bengkulu 2014-2016. Bengkulu: Badan Pusat Statistik Provinsi Bengkulu. www.bengkulu.bps.go.id

BPS. (2008). Provinsi Bengkulu dalam Angka 2008. Bengkulu: Badan Pusat Statistik Provinsi Bengkulu. www.bengkulu.bps.go.id

BPS. (2003). Provinsi Bengkulu dalam Angka 2003. Bengkulu: Badan Pusat Statistik Provinsi Bengkulu. www.bengkulu.bps.go.id

Bendavid-Val. A. (1991). Regional and Local Economic Analysis for Practitioners. $4^{\text {th }}$ edition. Praeger.

Blakely. E. J. \& Bradshaw. T. K. (2002). Planning Local Economic Development: Theory and Practice. $3^{\text {rd }}$ edition. USA: Sage Publications.

Herawati, N. R. Pemekaran Daerah di Indonesia. http://ejournal.undip.ac.id

Hoover. E.M. \& Giarratani. F. (1984). An Introduction to Regional Economics. 3th edition. New York: Alfred A. Knopf.

Kuncoro. M. (2003). Metode Riset untuk Bisnis dan Ekonomi: Bagaimana meneliti \& menulis tesis?. Jakarta: Erlangga.

Kuncoro. M. (2012). Perencanaan Kabupaten/kota (Bagaimana Membangun Ekonomi Lokal. Kota dan Kawasan?). Jakarta: Salemba Empat.

Undang Undang No 3 Tahun 2003 tentang Pembentukan Kabupaten Muko-muko. Kabupaten Seluma dan Kabupaten Kaur di Provinsi Bengkulu.

Undang Undang No 39 Tahun 2003 tentang Pembentukan Kabupaten Lebong dan Kabupaten Kepahiang di Provinsi Bengkulu. 
Undang Undang No 24 Tahun 2008 tentang Pembentukan Kabupaten Bengkulu Tengah di Provinsi Bengkulu.

Widodo. T. (2006). Perencanaan Pembangunan: Aplikasi Komputer (Era Otonomi Kabupaten/kota). Yogyakarta: UPP STIM YKPN. 